\title{
THE EUROPEAN BADGER MELES MELES FROM MIDDLE PLEISTOCENE TO EARLY HOLOCENE OF ITALIAN PENINSULA
}

\author{
Beniamino Mecozzi $\odot$ \\ PaleoFactory Laboratory, Department of Earth Science, Sapienza, University of Rome, P.le Aldo Moro 5, 00185, Rome, Italy.
}

\begin{tabular}{|c|c|}
\hline $\begin{array}{l}\text { KEYWORDS: } \\
\text { Mediterranean; } \\
\text { Carnivoran; } \\
\text { size variability. }\end{array}$ & $\begin{array}{l}\text { BULLET-Points AbSTRACT } \\
\text { - The first occurrence of Meles meles is form the late Early Pleistocene (1.3 Ma). } \\
\text { - European badger is widely widespread across Europe during the Early Pleistocene to } \\
\text { Late Pleistocene. } \\
\text { - The size variability of Meles meles is not linked to evolutionary trend through the } \\
\text { Middle Pleistocene to Early Holocene and/or considered as response to climatic } \\
\text { changes. }\end{array}$ \\
\hline
\end{tabular}

\section{INTRODUCTION}

True badgers (genus Meles) are widely spread across the Palearctic region, from the Iberian Peninsula to the Japanese archipelago (Macdonald, 2001; Proulx et al., 2016). The taxonomy and the relationships of the different species represent yet unresolved issues in the study of the Mustelidae family (Baryshinikov et al., 2003). Based on craniodental morphology, skull proportions, color patterns of the face marks and baculum structure, at least three distinct species can be identified: the European badger Meles meles Linnaeus, 1758 (spread in Europe and Southwest and Central Asia), the Asian badger Meles leucurus Hodgson, 1847 (continental Asia) and the Japanese badger Meles anakuma Temminck, 1844 (Japan). In addition, molecular phylogenetic studies (Del Cerro et al., 2010; Tashima et al., 2011) and morphometric investigations (Abramov and Puzachenko, 2006; 2013) led to the distinction of badgers from Caucasus and Middle-East from the Eurasian stock, known as Meles canescens (Caucasian badger).

In Eurasian fossil record, the genus Meles Blanford, 1875 probably evolved from Melodon during the Ruscinian (early Pliocene) in the temperate forests of Asia (Kurtén, 1968). The early representatives of the genus were widespread throughout the Europe (Neal \& Cheeseman, 1996), reaching the Iberian Peninsula during the Plio-Pleistocene transition (MadurellMalapeira et al., 2009). According to several authors (Madurell-Malapeira, 2010; Madurell-Malapeira et al., 2011a), the remains from early to middle Villafranchian sites (Pliocene to Early Pleistocene) of Europe can be referred to a single species, Meles thorali. This species differs from its descendant $M$. meles in several cranial and dental features (see MadurellMalapeira et al., 2011a). Albeit several badger species/ subspecies were established on fossil specimens from the late Villafranchian to early Aurelian faunal assemblages of Europe (Meles thorali spelaeus Bonifay, 1971; Meles dimitrius Koufos, 1992; Meles hollitzeri Rabeder, 1976; Meles atavus Kormos, 1914), all the badger remains from the late Early to Late Pleistocene have recently been reconsidered as ecomorphotypes of the highly variable M. meles (Madurell-Malapeira et al., 2011b).

In the Italian fossil record, the presence of this carnivoran is reported by few localities from Early to Middle Pleistocene (Mecozzi et al., 2019). Its first occurrence is from the late Villafranchian site of Pirro Nord (Pirro 10) (Apulia, southern Italy), represented by a mandibular fragment (Petrucci et al., 2013). Although the European badger is a common element of the Middle to Late Pleistocene mammal assemblage (see Mecozzi et al., 2019), its materials are rarely studied and described, with the exception for a splanchnocranial portion from the Italian site of Ingarano (Iurino, 2014).

The morphometric comparisons of European badger from Early to Late Pleistocene sites of Italian Peninsula is here presented, in order to investigate the variability of fossil material.

\section{Material \& Methods}

The sample of Meles meles is housed in several Italian Institutions and Museums were used as standard extant comparison (Tab. 1): fossil collections from the Middle Pleistocene sites of Casal Selce, G.R.A. Km2, 


\begin{tabular}{lcclll}
\hline \multicolumn{1}{c}{ Site } & Abbrevation & Region & Age & MIS & Reference \\
\hline Cava di Breccia & CBr & Italian Peninsula & Middle Pleistocene & 16 & This work \\
G.R.A. Km 2 & G.R.A. & Italian Peninsula & Middle Pleistocene & 12 & This work \\
Melpignano & Mel & Italian Peninsula & Middle Pleistocene & $9-8$ & This work \\
San Sidero & SSi & Italian Peninsula & Late Pleistocene & $9-8$ & This work \\
Torre del Pagliaccetto & TPa & Italian Peninsula & Middle Pleistocene & 7 & Caloi \& Palombo (1978) \\
Grotta Cucigliana & GCu & Italian Peninsula & Late Pleistocene & 5 & Del Campana (1914) \\
Grotta Laceuduzza & GLa & Italian Peninsula & Late Pleistocene & 4 & This work \\
Grotta Uluzzo C- III & GUC-III & Italian Peninsula & Late Pleistocene & 4 & This work \\
Avetrana & Ave-8 & Italian Peninsula & Late Pleistocene & 3 & This work \\
Buca della lena & BdI & Italian Peninsula & Late Pleistocene & 3 & Pitti \& Tozzi (1971) \\
Grotta Masseria del Monte & GMM & Italian Peninsula & Late Pleistocene & 3 & Anelli (1959) \\
Fondo Focone & FFo & Italian Peninsula & Late Pleistocene & 2 & This work \\
Grotta della Fornace & GdF & Italian Peninsula & Late Pleistocene & 2 & Fabiani (1919) \\
Santa Maria d'Agnano - Esterno & SMA-E & Italian Peninsula & Late Pleistocene & 2 & This work \\
Grotta Romanelli & GRo & Italian Peninsula & Early Holocene & 1 & This work \\
Extant Meles meles & Ext & Italian Peninsula & & This work \\
\hline
\end{tabular}

Tab. 1. Extant and fossil remains from Middle Pleistocene to Early Holocene of Meles meles from Italian Peninsula.

Melpignano and San Sidero, and the Late Plesitocene sites of Avetrana and Early Holocene site of Grotta Romanelli are stored at the PaleoFactory Laboratory, Department of Earth Science, Sapienza, University of Rome; those from the Late Pleistocene sites of Grotta Laceduzza and SMA-esterno to at the Museo delle Cività preclassiche della Murgia Meridionale, Ostuni (Brindisi); those from the Late Pleistocene site of Fondo Focone at the Istituto Italiano di Paleontolgia Umana (IsIPU); those from the Late Pleistocene site of Grotta Uluzzo C at the Museo di Storia Naturale, Sezione di Geologia e Paleontologia, dell'Università di Firenze (Florence).

As comparison material extant badgers from Italian Peninsula has been used, belonging to the collections of the following Institutions: Museo di Storia Naturale G. Doria, Genova; Museo Friulano di Storia Naturale, Udine; Museo Civico di Storia Naturale, Milano; Museo di Zoologia dell'Istituto Superiore per la Protezione e la Ricerca Ambientale, Ozzano dell'Emilia (Bologna). According to von den Driesch (1974), 3 dental variables have been considered: the length of upper carnassial $\left(\mathrm{P}^{4} \mathrm{~L}\right)$, length of the upper first molar $\left(\mathrm{M}^{1} \mathrm{~L}\right)$ and length of the lower carnassial $\left(\mathrm{M}_{1} \mathrm{~L}\right)$. The measurements were taken to the nearest $0.1 \mathrm{~mm}$ with a digital calliper. Literature data on fossil badgers from the Middle to Late Pleistocene sites of Italy used here are reported in Tab. 1 . The variation in size of upper carnassial $\left(\mathrm{P}^{4} \mathrm{~L}\right)$, upper first molar $\left(\mathrm{M}^{1} \mathrm{~L}\right)$ and length of the lower carnassial $\left(\mathrm{M}_{1} \mathrm{~L}\right)$ of the late Early to Early Holocene is tested throughout the time.

\section{Discussion}

The upper and lower teeth of M. meles from all the considered Pleistocene sites show a moderate variability, excepted for lower carnassial (Fig. 1). The size upper carnassial is quite constant and no difference can be detected through the Middle Pleistocene to Early Holocene (Fig. 1). However, the $\mathrm{P}^{4} \mathrm{~L}$ in fossil $M$. meles is larger than in the extant Italian badger (Fig. 1). The dimension of the upper first molar of the fossil specimens falls in the large values of the variability of the extant M. meles (Fig. 1). The reduced values in the $\mathrm{M}^{1}$ were detected from the Middle Pleistocene site of Melpignano and Late Pleistocene site of Fondo Focone (Fig. 1).

Considering the lower carnassial, the fossil sample is larger on average than the extant Italian badger (Fig. 1). The size variability of the lower carnassial cannot be linked to evolutionary trend or geographical difference. The larger specimens are from the Middle Pleistocene samples site of G.R.A. Km2 and from the Late Pleistocene of Grotta Laceduzza and Fondo Focone; the range dimension of these specimens falls out the variability of the extant Italian badger.

The extant European badger possesses a high ecological tolerance, able to occupy a wide habitat range, with different climatic condition. Its wide distribution reflects the large phenotypic and genotypic variability, which led the identification of at least three distinct species. According to Mecozzi et al. (2019), the fossil M. meles from the Pleistocene European sites shows a large craniodental variability, albeit the scarcity of fossils and their distribution over a large temporal and spatial scale, characterized by different climatic and ecological conditions. Due to this variability, the identification of a possible clinal variation and/or evolutionary trend is complicated. 


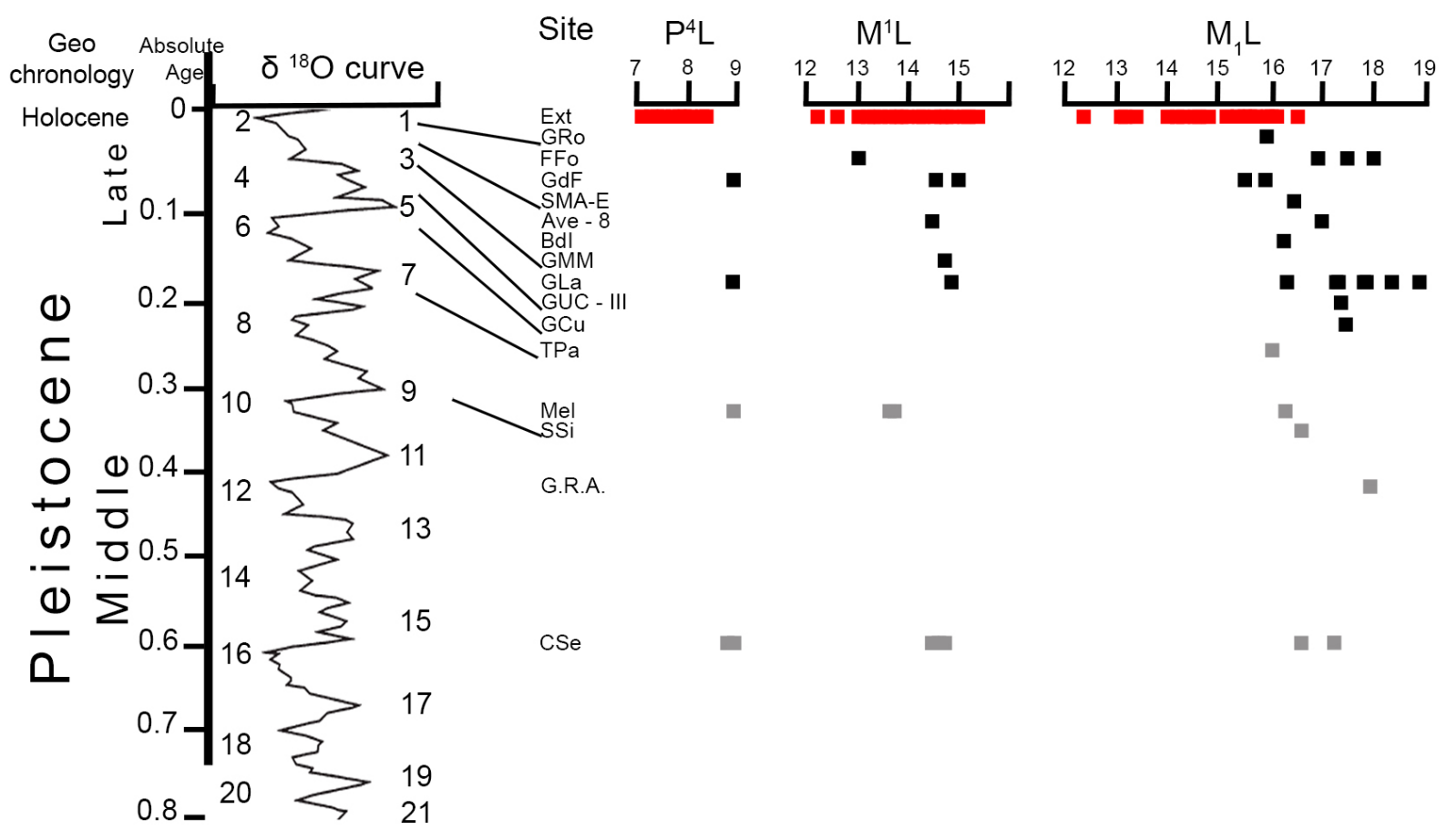

Fig. 1. Size variation in Meles meles, as indicated by the length of the upper carnassial $\left(\mathrm{P}^{4} \mathrm{~L}\right)$, upper first molar $\left(\mathrm{M}^{1} \mathrm{~L}\right)$ and lower carnassial $\left(\mathrm{M}_{1} \mathrm{~L}\right)$. Geochronology, age in millions of years and Oxygen isotope curves (after Shackleton, 1995) on the left, next the fossiliferous sites and their suggested ages indicated by line. Colors: red - extant specimens; black - Late Pleistocene to Early Holocene specimen; grey - Middle Pleistocene specimen.

The morphological and morphometric variability of fossil European badgers led the proliferation of several different evolutionary hypotheses and several species/ subspecies, such as Meles thorali spelaeus (late Middle Pleistocene, Lunel-Viel, France), Meles dimitrius (Early Pleistocene, Gerakarou and Apollonia, Greece), Meles hollitzeri (Early Pleistocene, Untermassfeld, Germany, and Deutsch-Alternburg 2, Austria), Meles atavus (Middle Pleistocene, Betfia-5, Hungary). An alternative scenario was recently proposed by Madurell-Malapeira et al. (2011b), which attributed the remains from the late Early Pleistocene to Late Pleistocene to a single species $M$. meles.

Considering the fossil sample from the Italian Peninsula, there is no morphometric differences among the specimens from early Middle Pleistocene, late Middle Pleistocene, Late Pleistocene and Early Holocene sites. Whilst the length of both upper carnassial and upper first molar is quite constant through the time; the length of lower first molar is huge variable. Despite this, its variability fails to reflect evolutionary trend trough the time and/or size variation as response to climate. For instance, the specimens from the Last Glacial sites (MIS 2, Late Pleistocene) of Fondo Focone, Grotta della Fornace and SMA-esterno show a large morphometric variability, which completely fall in the dimensional range of both fossil and extant materials.

\section{Conclusion}

A large sample of European badger from Middle Pleistocene to Early Holocene of the Italian Peninsula was here analyzed. The morphometric comparison of the fossil and the extant specimens confirms the moderate size variability of this carnivoran. This size variation seems to be not linked to evolutionary trend through the Middle Pleistocene to Early Holocene and/or considered as response to climate. In this scenario, in accordance with Madurell-Malapeira et al. (2011b), the European fossil record should be referred to a highly polymorphic species $M$. meles.

\section{ACKNOWLeDgments}

The author is thankful for granting access to the material, the kindness and availability of: Luciano Bruni and Stefano Grimaldi ("Istituito Italiano di Palentologia Umana (IsIPU)", Anagni); Elisabetta Cioppi (curator of the "Museo di Paleontologia del Sistema Museale dell'Università di Firenze", Florence). I thank Raffaele Sardella, supervisor of my $\mathrm{PhD}$ project, for his constant support and helpful advice. I thank J. Conti, D.A. Iurino, A. Iannucci, I. Mazzini, A. Profico and F. Strani for their useful suggestions and help. This work was supported by Grandi Scavi 2016 (ref. SA116154CD9592F3), Grandi Scavi 2017 (ref. SA11715C81468801), Grandi Scavi 2018 (ref. SA1181642D3B3C58), Grandi Scavi 2019 (ref. SA11916B513E7C4B) of Sapienza, University of Rome, 
resp. Raffaele Sardella.

\section{REFERENCES}

Abramov A.V. \& Puzachenko A.Y. (2006). Geographical variability of skull and taxonomy of Eurasian badgers (Mustelidae, Meles). Zoologicheskii Zhurnal, 85: 641-655.

Abramov A.V. \& Puzachenko A.Y. (2013). The taxonomic status of badgers (Mammalia, Mustelidae) from Southwest Asia base on cranial morphometrics, with the redescription of Meles canescens. Zootaxa, 3681(1): 44-58. https://doi.org/10.11646/zootaxa.3681.1.2

Anelli F. (1959). Prime ricerche paleontologiche della grotta della Masseria del monte Conversano (Murge di Bari). Le grotte d'Italia , 3: 1-27.

Baryshnikov G.F., Puzachenko A.Y. \& Abramov A.V. (2003). New analysis of variability of cheek teeth in Eurasian badgers (Carnivora, Mustelidae, Meles). Russian Journal of Theriology, 1: 133-149.

Blanford W.T. (1875). Descriptions of new Mammalia from Persia and Balúchistan. Annales de Magazine of Natural History, 4(16): 309-313. https://doi. org/10.1080/00222937508681858

Bonifay M.F. (1971). Carnivores quaternaries du Sud-Est de la France. Mèmoires du Musèum National d'Historie Naturelle Nouvelle Sèrie C Tome, 21(2): 1-377.

Caloi L. \& Palombo M.R. (1978). Anfibi, rettili e mammiferi di Torre del Pagliaccetto (Torre in Pietra, Roma). Quaternaria, 20: 315-428.

Del Campana D. (1914). Mammiferi nuovi o poco noti della Grotta di Cucigliana (Monti Pisani). Bollettino della Società Geologica Italiana, 31: 412-418.

Del Cerro I., Ferrando A., Marmi J., Chashchin P., Taberlet P. \& Bosch M. (2010). Nuclear and mitochondrial phylogenies provide evidence for four species of Eurasian badgers (Carnivora). Zoologica Scripta, 39: 415-425. https://doi.org/10.1111/j.1463-6409.2010.00436.x

Driesch Von den A. (1976). A guide to the measurement of animal bones from archaeological sites. Peabody Museum Bulletins, 1: 1-137.

Fabiani R. (1919). I Mammiferi Quaternari della regione veneta. Memorie dell'Istituto di Geologia della Regia Università di Padova, 5: 1-173.

Hodgson B.H. (1847). On the Tibetian badger (Taxidea leucurus). Journal of the Asiatic Society of Bengal, 16: 763771.

Iurino D.A. (2014). Body size reduction and tooth agenesis in Late Pleistocene Meles meles (Carnivora, Mammalia) from Ingarano (Southern Italy). Rivista Italiana $d i$ Paleontologia e Stratigrafia (Research In Paleontology and Stratigraphy), 120(1): 109-118. https://doi. org/10.13130/2039-4942/6053

Kormos T. (1914). Drei neue Raubtiere aus den Präglazial Schichten des Somlyòhegy bei Püspükfürdö. Mitteilungen aus der Jahrberichte Königliche Ungarische Geologische Reichsanstalt, 22: 223-247

Koufos G.D. (1992). The Pleistocene carnivores of the Mygdonia basin. Annales des Paleontologie 78: 205-257

Kurtén B. (1968). Pleistocene mammals of Europe. Aldine Publishing Co, Chigago, 317 pp.

Linnaeus C. (1758) Systema naturae per regna tria naturae, secundum classes, ordines, genera, species, cum characteribus, differentiis, synonymis, locis. In: Tomus, vol I. Laurentius Salvius, Stockholm,p 824
Macdonald D.W. (2001). The new encyclopedia of mammals. Oxford University Press, Oxford, 930 pp.

Madurell-Malapeira J. (2010). The Villafranchian carnivores from the north-eastern Iberian Peninsula and the EarlyMiddle Pleistocene transition. Dissertation, Universitat Autònoma de Barcelona, Cerdanyola del Vallès.

Madurell-Malapeira J., Santos-Cubedo A., Marmi J. (2009). Oldest European occurrence of Meles (Mustelidae, Carnivora) from the Middle Pliocene (MN16) of Almenara-Casablanca-4 karstic site (Castellòn, Spain). Journal of Vertebrate Paleontology, 29: 961-965. https:// doi.org/ 10.1671/039.029.0322

Madurell-Malapeira J., Alba D.M., Marmi J., Aurell J. \& Moyà-Solà S. (2011a). The taxonomic status of European Plio-Pleistocene badgers. Journal of Vertebrate Paleontology, 31(5): 885-894. https://doi.org/10.1080/ 02724634.2011.589484

Madurell-Malapeira J., Martínez-Navarro B., Ros-Montoya S., Espigares M.P., Toro I. \& Palmqvist P. (2011b). The earliest European badger (Meles meles), from the Late Villafranchian site of Fuente Nueva 3 (Orce Granada, SE Iberian Peninsula). Comptes Rendus Palevol 10(8): 609-615. https://doi.org/10.1016/j.crpv.2011.06.001

Mecozzi B., Coppola D., Iurino D.A., Sardella R. \& De Marinis A.M. (2019). The Late Pleistocene European badger Meles meles from Grotta Laceduzza (Brindisi, Apulia, Southern Italy): the analysis of the morphological and biometric variability. The Science of Nature, 106(5-6): 13. https://doi.org/10.1007/s00114 $019-1604-2$

Neal E. \& Cheeseman C. (1996). Badger. Tand AD Poyser Ltd, London, $271 \mathrm{pp}$.

Petrucci M. Cipullo A., Martínez-Navarro B., Rook L. \& Sardella R. (2013). The late Villafranchian (Early Pleistocene) carnivores (Carnivora, Mammalia) from Pirro Nord (Italy). Palaeontogrhica Abteilung A, 298(1-6): 113-145.

Pitti C. \& Tozzi C. (1971). La Grotta del Capriolo e la Buca della Iena presso Mommio (Camaiore, Lucca). Rivista di Scienze Preistoriche, 26: 213-258.

Proulx G., Abramov A.V., Adams I., Jennings A.P., Khorozyan I., Rosalino L.M., Santo-Reis M., Veron G. \& Do Linh San E. (2016). World distribution and status of badgers - a review. Systematics, Biology, Conservation, and Research Techniques. Alpha Wildlife Publications, Sherwood Park, Badgers, pp 31-116.

Rabeder G. (1976). Die Carnivoren (Mammalia) aus dem Altpleistozän von Deutsch-Altenburg 2. Mit Beiträgen zur Systematik einiger Musteliden und Caniden. Beiträge Paläontologie Osterreich, 1: 5-119.

Shackleton N.J., (1995). New data on the evolution of pliocene climatic variability. In: Vrba E.S., Denton G.H., Partidge T.C. and Burckle L.H. (Eds.) Paleoclimate and Evolution, with Emphasis on Human Origins. Yale University Press, New Haven. 242-248.

Tashima S., Kaneko Y., Anezaki T., Baba M., Yachimori S., Abramov A.V., Saveljev A.P. \& Masuda R. (2011). Phylogeographic sympatry and isolation of the Eurasian badgers (Meles, Mustelidae, Carnivora): implication for an alternative analysis using maternally as well as paternally inherited genes. Zoological Science, 28: 293-303. https://doi.org/10.2108/zsj.28.293.

Temminck C. (1844). Apercu general et specifique sur les mammiferes qui habitent le Japon et les Iles qui en dependant. In: von Siebold P (ed) Fauna japonica. Muller, Amsterdam, pp 25-59. 